\title{
Research on the Sharing Mechanism of the Scholarship of Teaching and Learning in Teacher Development Center of Higher Vocational Colleges
}

\author{
Junfei $\mathrm{Li}^{*}$ \\ Office of Academic Affairs, Suzhou Institute of Trade\&Commerce, Suzhou, Jiangsu, 215009, China \\ *Corresponding author. Email: peoplepeople@163.com
}

\begin{abstract}
This paper first analyzed the basic principles of the scholarship of teaching and learning of the teacher development center in higher vocational colleges, and on this basis, and it proposed that establishing the teaching scholarship sharing mechanism of teachers' development center in higher vocational colleges, should be constructed from the following five aspects: the establishment of cooperation mechanism, the expansion of cultural brand influence, the gathering of innovative cultural resources, the improvement of teachers' teaching ability and the strengthening of teachers' teaching reflection ability, and the main strategies of the teaching scholarship sharing mechanism are put forward.
\end{abstract}

Keywords: Higher vocational colleges, Teacher development center, Scholarship of teaching and learning, Sharing mechanism.

\section{RAISE OF PROBLEM}

American universities have always attached great importance to the development of teachers. The Center for Learning and Teaching Research, established in 1962 at the University of Michigan, is a high-level training and learning organization in the United States that provides teachers with a wide range of professional services. The special report "Reflection on Academic Level" published in 1990 by Boyer, the former President of The Carnegie Foundation for Teaching Promotion in the United States, proposed the "Scholarship of Teaching", advocating the inclusiveness and mutual permeability of academic activities, which has promoted the scholarship of teaching as the goal orientation of the Center for Teacher Development in American colleges and universities. In China, the researches on scholarship of teaching and culture of teaching were carried out separately. In terms of the research of teaching culture, Professor Wu Daguang (2013) of Xiamen University believed that the teaching culture of a university was the culture that reflected the functions of a university, and from the perspective of the construction of modern university system, the construction of teacher teaching development center was not only a problem of institution establishment, but also a problem of how to establish an institution construction that was compatible with the teaching culture that embodied the various functions of university. In terms of teaching scholarship, Professor Hou Dingkai of Institute of Higher Education of East China Normal University (2010) pointed out that teaching and academic research had gradually become an international higher education reform movement in recent years, both in terms of theoretical construction and institutional practice, and it was reflected in the practice, evaluation and reflection of scholarship of teaching, and the institutionalization of scholarship of teaching began to take shape. Bu Yayun of Huzhou Vocational and Technical College pointed out (2015) that the Teacher Development Center was a powerful carrier to promote the professional development of teachers at the school-based level. However, the construction of Teachers Development Center in higher vocational colleges was in the spontaneous stage, and there was a lack of experience in teacher development platform design according to the characteristics of higher vocational students, teaching characteristics and teacher requirements. To sum up, due to various historical and realistic reasons, the construction time of teacher development center in higher vocational colleges in China is relatively short. At present, there 
are few researches and practices on teacher development center of higher vocational colleges in China. This paper focuses on the sharing mechanism of scholarship teaching and learning in Teacher Development Center of higher vocational colleges, which to a certain extent expands the research vision of Teacher Dvelopment Center of higher vocational colleges.

\section{BASIC CONCEPTUAL ANALYSIS}

Teacher Development Center refers to an academic service institution independently established by colleges and universities to promote the professional development of teachers. The main tasks of the center are to improve teachers' teaching ability, encourage teaching reform and practice, develop university teaching scholarship and build teachers professional community. This topic refers to the teacher development center setted up in higher vocational colleges.

Culture of scholarship of teaching refers to the values, ways of thinking, spiritual pursuit and behavior patterns formed by teachers in higher vocational colleges in the process of teaching reform, curriculum innovation and teaching research. The integration of quality culture in higher vocational colleges is a unique academic culture which is different from ordinary undergraduate colleges.

Teaching scholarship sharing mechanism means to build the teaching community in which teacher can help to share and communicate new thinking of the scholarship of teaching and learning in higher vocational colleges. This mechanism is conducive to improving the classroom teaching effect of schools, meeting the personalized and diversified learning needs and appeals of students, promoting teachers to constantly reflect on the teaching work, and effectively improving the quality of talent training.

To sum up, as an academic support service institution specially established to improve teachers' teaching quality and ability, the teacher development center of higher vocational colleges, under the background of the "Double High Plan" launched by the state, pays more attention to the sharing effect of teachers' development quality resources through the way of college cooperation. And through the teaching scholarship sharing mechanism, teachers of different disciplines, majors and courses form an academic community, take teaching as an academic form and value pursuit, and form a specific teaching philosophy and code of conduct system to be observed by all. For higher vocational colleges, the culture of teaching scholarship is a specific type one, as well as a quality culture based on action-oriented teaching context. The culture of the scholarship of teaching and learning of higher vocational colleges has an internal and continuous driving force for the standardization, form and quality of teachers' teaching.

\section{BASIC PRINCIPLE OF ESTABLISHING THE SCHOLARSHIP OF TEACHING AND LEARNING SHARING MECHANISM}

First, stick to the principle of regionalization. To establish the scholarship of teaching sharing mechanism, the teacher development center must serve the strategy of urban industrial transformation and upgrading and the task of regional modernization. Therefore, the development orientation of urban functions determines that the teaching scholarship operation mechanism of the center adheres to the principle of regionalization. The center should incorporate the history and culture of the city, the enterprise culture of well-known local companies, and the education culture of demonstration vocational colleges into the center's teacher teaching and training programs, effectively connect the urban industry development planning and the market demand of technical and technical talents with the curriculum training and teaching content of higher vocational colleges, establish an innovation and entrepreneurship education and training team jointly participated by industry authorities, social investment institutions and enterprise managers, improve the teaching level of innovation and entrepreneurship of teachers in higher vocational colleges, and provide high-quality teachers for technical and technical talents, innovation and entrepreneurship training in various cities in Southern Jiangsu province.

Second, stick to the principle of characterization. According to the distinctive characteristics of the urban development orientation, industrial structure layout, local history and culture of higher vocational colleges, the establishment of teaching scholarship sharing of teacher development center should match with the development of the city, so as to build a regional teacher development center with the regional characteristics of South of Jiangsu Province. For example, if a city takes tourism as a priority, it should build a teaching academic center with tourism characteristics, and priority should be given to all local vocational college teachers majoring in tourism, part-time teachers in tourism enterprises, and school-enterprise double tutor teams to carry out apprenticeship pilot programs, and also systematic and continuous professional teaching training should be conducted to enable teachers to master principles of modern vocational education and teaching theories, expand and enhance teachers' comprehensive teaching ability, and give play to the cultural influence of teachers' center in serving urban development.

Third, stick to the principle of collaboration. The establishment of the regional teacher development center involves two stakeholders of different 
organizational attributes, namely enterprises and higher vocational colleges. It breaks through the single and closed development mode of the former teacher development center of higher vocational colleges, which is an innovative move to explore the teaching academic culture of higher vocational teachers. The teacher development center can give full play to the superior effect of school-enterprise cooperation and implement a series of teacher teaching training programs with distinctive features of integration of production and education by means of salon dialogue and training programs. By improving the academic ability of teacher teaching, the sustainable development ability of teachers' career will be further enhanced, and the teacher development center will become a shared platform for school-enterprise cooperation to improve the academic ability of teacher teaching.

\section{MAIN STRATEGIES OF ESTABLISHING TEACHING AND ACADEMIC SHARING MECHANISM}

As for the location of the teacher center, it can be set up in the local national "double High Plan" vocational colleges, or in the enterprise universities of well-known enterprises in the city, and other schools and enterprises can participate as member units. In the selection and recruitment of training teachers, the center can employ famous teachers of higher vocational colleges, famous professors of universities, directors of human resources of enterprises, backbone of technology and management of enterprises, leaders of industry associations and local cultural celebrities as stable training teachers. In the work of the center, a series of activities, such as centralized observation of teaching by famous teachers and edification of urban culture, have been carried out to improve teachers' professional teaching ability and taste of cultural quality. In terms of funds input, schools and enterprises may jointly invest in the establishment of a special fund or a foundation organization to ensure the implementation of the teaching and academic sharing project training activities of the teacher Development Center, then to establish a collaborative mechanism and become a "workshop" for teachers' teaching, academic and business training and exchange.

The realization of the modernization goal of local vocational education cannot be separated from a common meeting point, that is, the improvement of the overall quality and ability of technical and technical talents. Therefore, the establishment of the teaching and academic sharing mechanism of the teacher development center with urban characteristics should take the initiative to serve the urgent task of teachers' teaching ability construction in higher vocational colleges from the macro level of urban development and in combination with the demand trend of technical and technical talents in the industry. The teacher center should carry out teaching academic activities in such projects as in-post practice teaching, teacher teaching ability evaluation, social training, urban humanities and arts training, cultivate teaching community, and enhance the appeal of teachers to actively participate in project training. In addition, the center should design academic evaluation indexes for teachers' teaching of different major groups in different cities, organize teachers to participate in classroom teaching competition of the same city, regularly carry out evaluation and improvement of teachers' teaching quality and build the center into an academic platform of vocational education think tank with greater cultural influence in the city, then to expand the influence of cultural brands and become a "new think tank" for the innovative development of vocational education in cities.

Under the background of urban innovation-driven development strategy, modern cities need high-quality technical and technical talents with mass entrepreneurship and innovation ability. Therefore, teaching scholarship sharing type development center should expand the function of teachers, and it is necessary to make use of the cross-boundary resource integration advantage of the center, highlight the edification of innovation and entrepreneurship culture, carry out the training of teachers' innovation and entrepreneurship thinking and teaching ability, and conduct a special discussion on the innovation and entrepreneurship education and teaching problems in higher vocational colleges. The center should take the initiative to set up docking channels with urban business incubators, mass innovation Spaces and investment institutions. The center also should establishe a resource platform for innovation and entrepreneurship courses with regional characteristics to provide typical teaching cases for higher vocational colleges to carry out innovation and entrepreneurship education, and absorb and drawslessons from excellent enterprise culture in teaching and learning, thus forming a unique academic and cultural atmosphere featuring "double subjects" to educate students, which will gradually improve the innovation and entrepreneurship ability of technical talents. Thus can gather innovative cultural resources and become the incubator of innovative education and teaching for teachers.

The education and teaching level of teachers in higher vocational colleges directly determines the quality of running a school. Improving teachers' teaching ability is the core content for teachers' development center in higher vocational colleges to carry out Shared teaching academic research. Specifically, it includes teachers' knowledge ability, language expression ability, education, teaching and research ability, application ability of information technology, etc. Teachers summary, concise and improve the level of teaching ability in the process of continuous teaching practice. We should encourage 
teachers to actively research the latest teaching methods at home and abroad, explore the most cutting-edge teaching mode, research problems, share problems, demonstrate problems, and train teachers of higher vocational colleges with lofty spiritual realm, lofty professional ethics and tireless spirit of study. In the process of teaching practice, the teaching ability level is constantly improved to establish teachers' teaching ability and boost the sustainable development of teachers' education and teaching level.

The Teacher Development Center is the supporting service organization of the scholarship of teaching in higher vocational colleges. The important function of the center is to pay attention to the growth of teachers' career, lay emphasis on personalized teaching style, improve the level of teaching research, and meet the diversified learning needs of different students in higher vocational colleges based on the philosophy of teaching reflection. According to The Japanese educator Satoshi Sato, teachers will gradually become "reflective practitioners" in the professional development by examining and considering the problems at the front line of teaching. Therefore, the essence of teachers' teaching scholarship is self-reflection, inspiring students to be good at active learning in the teaching context integrating theory and practice, and cooperative learning in task-driven project course teaching, so as to cultivate the vocational quality and craftsman spirit of contemporary higher vocational students, and form a "growth garden" of reflection on the scholarship of teaching.

\section{CONCLUSION}

Teachers' development center in higher vocational colleges should pay attention to important function of the teaching scholarship sharing mechanism, which include the establishment of cooperation atmosphere, the expansion of cultural influence, innovative cultural resources, the improvement of teachers' teaching ability and the strengthening of teachers' teaching reflection ability.

\section{AUTHORS' CONTRIBUTIONS}

Junfei Li contributed to the conception and analysis of the full study;

\section{ACKNOWLEDGMENTS}

This research was financially supported by the 13th Five-Year Plan for Education Science in Jiangsu Province in 2016, project No: B-a /2016/03/09.

\section{REFERENCES}

[1] Wang Xia, Cui Jun.Construction of University Teaching Development Center [J]. Jiangsu Higher Education, 2013 (1): 34-37.

[2] Wang Yuheng. Making Teaching a common Treasure -- Interpretation of Teaching Scholarship Thoughts of Shulman University [J].Comparative Education Research, 2006,(5) : 52

[3] Song Yan. Scholarship of Teaching And Institutional Guarantee of University [M]. Beijing: Central Compilation and Translation Press, 2013:96-97

[4] He Xiaolei. Research on Scholarship of Teaching in American Universities [M]. Beijing: China Social Sciences Press, 2016:161.

[5] Ernest.Boyer. Reflection on Academic Level -A Key area of Professors' Work/Famous literature on contemporary Foreign Educational Reform (Volume 3, USA) [C].Beijing: People's Education Press, 2004:24.

[6] Shulman LS.Teaching as Community Property: Putting an End to Pedagogical Solitude Change. Change, 1993, (25). 